\title{
浅析特殊地段的隧道开挖施工
}

\author{
王文博 \\ 中国水利水电第八工程局有限公司 \\ DOI:10.32629/btr.v3i3.2933
}

[摘 要] 隧道开挖施工非常复杂, 特别是特殊地段, 因此为了保障隧道开挖施工的顺利开展, 本文阐述了特殊地段的隧道开挖施工问题以及隧道 开挖施工的主要施工技术,对特殊地段的隧道开挖施工进行了探讨分析。

[关键词] 特殊地段; 隧道开挖施工; 问题; 施工技术; 要点

随着城市化的不断推进, 使得隧道工程建设日益增多, 基于此, 以下结 合特殊地段的隧道工程为例, 对其开挖施工进行了探讨分析。

\section{1 特殊地段的隧道开挖施工问题分析}

1. 1 岩体问题

隧道内的岩体处于整体状态, 并且不同地区的岩石结构也会有所不 同。而且隧道开挖有可能会导致岩土坍塌等现象, 并形成岩体断层, 如果出 现断层较大, 将严重影响隧道工程建设的顺利实施。所以对隧道开挖施工 过程中的岩体问题, 必须对岩石开展探测研究, 在其实际施工过程中, 争取 既保障岩石结构, 又可以避免发生岩体危害。

\section{2稳定性问题}

开挖施工稳定是保障隧道工程建设顺利开展的关键, 但是在实际的施 工过程中, 处理稳定问题的难度非常大, 并且稳定问题涉及的范围比较大, 如隧道跨越式处理不稳定、爆破不稳定、加固结构不稳定等, 都会导致隧 道施工搁置, 因此必须对隧道中的稳定问题, 实行技术优化处理, 从而保障 隧道开挖施工的稳定性。

\section{2 隧道开挖施工的主要施工技术}

2.1盾构法

其是以盾构这种施工机械暗挖隧道的施工技术, 优点表现为: 大部分 施工者在地下开展, 这样就不会影响地面交通, 又能够减少对居民影响; 穿 越河道时不影响航运; 施工不受风雨等气候条件的影响; 在地质条件差、 地下水位高的地方建设埋深较大的隧道, 盾构法具有经济优越性。

\section{2 新奥法}

其应用了围岩的自承能力和开挖面的空间约束作用, 以锚杆和喷射混 凝土为主要支护手段, 对围岩进行加固, 约束围岩的松弛和变形, 并通过对 围岩和支护的量测、监控, 指导地下工程的设计施工。

\section{3浅埋暗挖法}

浅埋暗挖法是一项边开挖边浇筑的隧道施工技术, 适合于城市地区松 散土介质围岩条件, 隧道埋深小于或等于隧道直径, 地表沉降很小。其突出 优势为不影响城市交通, 无污染、无噪声, 而且适合于各种尺寸与断面形式 的隧道洞室。

\section{3 特殊地段的隧道开挖施工要点分析}

3. 1 超前支护

特殊地段的隧道开挖施工过程中, 初期支护体系作用是承担隧道工程 的围岩压力, 在充分考虑隧道工程的受力特点、地质条件、围岩等级、断 面结构等因素, 确定初期支护: (1) 超前针杆。通常需要结合开挖循环次数、 钻孔机械类型、针杆拉拔试验强度以及隧道工程地质条件等因素, 来确定 超前针杆的长度。超前针杆主要包括: 第一、悬吊式超前针杆, 沿开挖轮 廓线方向, 将悬吊式超前针杆的前端固定在稳定的岩层中, 超前针杆的末
端支撑在径向悬吊错杆上, 其主要作用是对拱部上方进行支撑, 确保爆破 作业之后的相应时间内, 围岩不会出现松驰坞塌现象。第二、支撑超前针 杆, 这种超前针杆形式的前端需要固定到稳定的岩层中, 未端应该连接到 钢架上。钢架结构一般有格栅拱架和钢拱架, 格栅拱架是通过焊接方式进 行制作, 而钢拱架是通过型钢冷弯方式进行制作。实际工程中, 特殊地段软 弱围岩支护方面, 钢架具有重要作用, 目前隧道工程多采用钢架支撑超前 针杆。(2) 超前管棚。根据钢管的长度进行划分, 可以将管棚分为小管棚和 大管棚两种形式。第一、小管棚法。这种施工方法所用到的钢管的直径在 50 毫米以内, 钢管的长度最大为 5 米。第二、大管棚法。其施工原理与小管 棚法类似, 大管棚法的循环长度需要按照实际工程要求进行设定, 一般控 制在 30 米以内。管棚施工注浆结束之后, 需要根据注浆材料确定开挖时间, 尽量减小注浆作业和开挖作业的时间间隔, 可以避免注浆固结现象, 降低 开挖难度。(3) 超前小导管预注浆。小导管预注浆法需要将钢管前端改变 为尖楔形状, 钢管前端的一定范围内, 设置相应数量的注浆孔。沿开挖轮廓 线, 按照规定的外插角进行钻孔作业, 同时, 将小导管打入孔洞中, 再将水 泥砂浆注入到小导管中, 确保围岩的空隙全部填充, 等到水泥砂浆固结之 后, 小导管注浆法施工结束, 这种方法适用于软弱围岩浅埋地段、断层破碎 带、砂卵石层、自稳性差的砂层等。

\section{2 超前灌浆施工要点}

其对于松散地层来说, 常采用注浆加固的方法, 将底层固结成一个统 一的整体, 再进行开挖作业。由于地层的构成不同, 需要采用不同的注浆材 料, 在粗砂、且存在侵蚀性水的地层中, 主要采用水泥砂浆作为注浆材料; 在细砂、粉砂或者存在侵蚀性水的地层中, 多以化学浆液为主要注浆材料。 此外, 确定洞内注浆段长度时, 应该充分考虑机械设备、注浆要求、地质条 件等因素, 通常将注浆段长度设定为 50 米, 极破碎岩层的注浆段长度控制 在 $5 \sim 10$ 米之间, 而破碎岩层的注浆段长度控制在 $10 \sim 15$ 米的范围内。

\section{4 结束语}

综上所述, 隧道开挖施工过程中, 具有隐蔽性大、作业空间有限、干扰 因素多、地质条件复杂等特点, 尤其是在特殊地段的开挖施工, 因此为了保 证其施工的顺利进行, 必须结合特殊地段的地质条件、围岩等级等, 合理开 展施工, 从而保障隧道工程质量。

\section{[参考文献]}

[1]惠彬永,刘建锁.特殊地段隧道开挖施工技术研究 [J]. 山西建 筑,2010,36(07):323-325.

[2]谢焦焦.青岛地铁隧道开挖引起地表沉降的控制研究 [D].青岛理工 大学,2017.

[3]王林昆.特殊地段的隧道开挖施工技术分析 [J]. 江西建 材,2014,(20):165. 